\section{Morley Segal}

Morley Segal, professor emeritus, School of Public Affairs, American University, Washington, D.C., died of complications from pancreatic cancer on April 18, 2008. He was 74.

Dr. Segal is widely known for his innovations in higher education and his role as the co-founder of an internationally recognized graduate program in organization development conducted jointly by American University and NTL Institute for Applied Behavioral Science. He published in leading political science and public administration journals and is best know for his book Points of Influence: A Guide to Using Personality Theory at Work (Jossey-Bass, 1997). The hallmark of all his work was a unique ability to bring together ideas from different disciplines integrated through mental models and typologies that made them accessible and useful to practitioners.

\section{Education as a Political Scientist}

Morley Segal was born on December 17, 1933, in San Francisco, the eldest son of Max and Edna Segal. He completed a BA in international relations from San Francisco State University in 1957 after a two-year stint in the U.S. Army where he served in Korea and Japan. Following that he received an MA in history from San Francisco State University in 1959 and went on to complete a Ph.D. in political science from Claremont Graduate School in 1965. He also worked as a legislative intern in the California Assembly in 1962-63 and wrote his doctoral dissertation on "The Role of Legislative Staff in the California Assembly." During his doctoral studies he started work at California State University at Hayward teaching American government in 1963. He was soon selected for a Congressional Fellowship in 196667 , which brought him to Washington, D.C., where he was recruited to join the faculty at American University by Professor Robert Cleary.

Dr. Segal officially joined the faculty of the School of Government and Public Administration (SGPA) at American University as an associate professor of public administration in 1967 and was appointed full professor of public administration in 1974. During his first four years, he taught undergraduate and graduate courses in political science and public administration, including study abroad programs and the famed Washington Semester program that drew undergraduates from universities around the country to learn more about government first hand.

\section{An Early Epiphany}

During his work with the study abroad and Washington Semester programs, Dr. Segal made an observation that shaped all his subsequent work. One of the features of these two programs was that students went through their courses as cohorts with the students staying together while the instructors and guest presenters changed. Always the astute observer, Dr. Segal soon recognized that what was happening in the classroom setting was as much, or more so, a function of what phase of group development the cohorts were going through as the students interacted with each other during the life of the course or semester. Were they in an early phase looking for direction and assurances, or perhaps, a later phase when they would challenge anyone in authority telling them anything? The same content presentation or instructor in one phase might be a resounding success, but if offered during a different phase there could be a contrary response. This led to an epiphany that shaped all his thinking and educational efforts thereafter: Process was as or more important than content! He immediately began putting this insight into practice in his teaching and also began to shift his professional focus from political science and public administration to organization behavior and group development. $\mathrm{He}$ also later wrote about his insights in an article called "Group Development and Innovative Teaching in Political Science," published in Teaching Political Science (October 1976).

\section{Shift in Focus to Organization Theory and Behavior and Organization Development}

By the early 1970s, Dr. Segal had begun teaching courses in organization theory and behavior in the graduate and undergraduate programs at American University. He also started looking for ways to expand the public administration curriculum to include more courses in a relatively new field that had emerged in the 1960s called organization development (OD). This field of practice drew heavily on psychology and socialpsychology and included a strong focus on team development processes. Process in one form or another now started to become a part of all his classes. This sometimes took the form of exercises or simulations to be debriefed so that students learned about the importance of process as well as the content they were studying. These forays into the world of both process and content moved his teaching style from behind the podium giving lectures to sitting amongst the students providing theoretical insights through more interactive methods. This won his courses a great following as well as devoted graduate students who couldn't wait to see what new course and methods Morley would come up with the next semester.

\section{Creating the AU/NTL Master of Science in Organization Development Program}

The occasion that led to one of his most significant accomplishments happened during a snowstorm in Omaha, Nebraska, in early 1978. Dr. Segal was on a business trip with Edie Seashore who was then president of NTL Institute and a pioneer in the applied behavioral sciences. While stuck in the airport waiting to get out they began to discuss the possibilities of a joint masters degree offered by American University and NTL Institute. NTL had long been intrigued by the possibility of creating its own degree-granting university, but that had never come to fruition. However, if NTL couldn't offer its own academic degree then perhaps it could partner with a university to do so, and maybe transform the university's way of thinking about higher education as well! For Professor Segal creating a joint masters degree program in organization development was just a short step from all the courses he had already put in place at SGPA.

Morley and Edie agreed to make it happen and enlisted Ms. Cornelia Eschborne at NTL and Professor Don Zauderer at SGPA to help design the course of study and recruit a faculty for what would become the AU/NTL joint masters degree program in organization development. Moving quickly, and to many people's surprise, a first class of about 28 students started January 1980. They formed AU/NTL Cohort I with Dr. Don Zauderer as the founding director of the program and Dr. Segal as the program's academic advisor. About two years later all 28 graduated with MPA degrees. The new program bore all the hallmarks of what Professor Segal believed and had learned about higher education. The students came through as cohorts so they could learn more about their own process and also support each other. The courses would be offered in an intensive twoweekend format, allowing people to work and attend school fulltime. The weekend format also permitted more experiential and process-oriented dimensions to be a regular part of each course. Courses were intended to reflect a balance of content, process, and application 
aided by a faculty drawn from American University and NTL Institute in a unique and still unprecedented collaboration.

Today, the AU/NTL Masters of Science in Organization Development Program continues to enroll students from around the world and has over 1,200 graduates. The program long ago had to stop designating cohorts in Roman numerals, and it most recently enrolled Cohort 57. Graduates of the program have gone on to make important contributions to the field and practice of organization development at conferences, in publications, through university teaching, and as OD practitioners and executives in business, government, and not-for-profit organizations. Importantly the program itself has served as a model and validation for the combination of content, process, and application in graduate education long advocated by Dr. Segal. There are no podiums to stand behind in the AU/NTL classroom.

\section{Becoming a Personality Theorist and Therapist}

Around this same time period, Dr. Segal became interested in Freud and psychoanalytic theories and approaches to group and organizational behavior. $\mathrm{He}$ then broadened his interests to include other psychological theorists and approaches such as Rogers, Jung, Horney, Skinner, Ellis, Lewin, and Perls. He began to incorporate their ideas into the classroom and then decided to write a book summarizing the essence of each of their theories and how it applied to the practice of organization development. It was a long labor of love, but was finally finished with the publication in 1997 of Points of Influence: A Guide to Using Personality Theory at Work. That same year Dr. Segal retired from the faculty at American University and was appointed professor emeritus. He moved back to San Francisco and completed the requirements to become a licensed marriage and family therapist and began a new career as a therapist at Pyramid Alternatives and in private practice. He was actively involved in his therapy practice and various writing projects until his untimely death.

\section{Morley Segal the Person}

In the end who was Morley Segal as a person? In some ways he was a study in contrasts. He was intellectually curious and had a keen mind combined with an amazing ability to pull disparate things together and see possibilities where others only saw obstacles. He had a healthy ego, but actively created opportunities for others to shine. At the same time his outward demeanor often belied his inner person. He was tall and a bit ungainly and in some ways the absent-minded professor. He was also able to laugh at himself or use himself as an example, such as learning how to tap dance and then using that as a way to model his Jungian "shadow self" as a suave character from the 1930s. These qualities made him approachable and endeared him to his colleagues and students. He was definitely charismatic, but in ways hard to fully define. From political scientist and legislative intern to personality theorist and therapist. From studying political and external dynamics to working with internal and unconscious processes. From a focus on content to a focus on content and process. A remarkable journey of a remarkable man who role modeled for his students and colleagues life-long learning, risk taking, personal empowerment, vulnerability, intellectual curiosity, and an uncanny ability to accomplish what others thought impossible.

Dr. Segal is survived by his loving life partner of nearly 30 years Maurine Poppers, his brother Rodney, his three children and their spouses, his six grandchildren, and his former wife, Joyce Holly. He is also survived by the thousands of colleagues and former students whose lives he enriched and influenced for more than 40 years.

Robert J. Marshak American University

\section{Note}

* This account was prepared by Dr. Robert J. Marshak, scholar in residence, School of Public Affairs, American University, who was a student and colleague of Morley Segal for 40 years.

\section{Charles Tilly}

Charles Tilly, a social scientist who deployed historical interpretation and quantitative analysis in the large scale study of social change, died on April 29 in New York City after a long illness. He was 78. Often focused on Europe since 1500 , his work also made sweeping advances in social and political theory. $\mathrm{He}$ leaves behind a panoply of former students, friends, and colleagues to whom he contributed wisdom, mentoring, and friendship over a long and distinguished career.

Tilly was born on May 27, 1929, in Lombard, Illinois, and was educated at Harvard and Oxford, obtaining the Ph.D. in sociology at Harvard in 1958. He taught at the universities of Delaware, Toronto, and Michigan, as well as at Harvard and the New School for Social Research, and ended his career at Columbia, where he was the Joseph L. Buttenwieser Professor of Social Science.

Tilly published over 50 books and more than 600 articles in the fields of social movements, revolutions, state building, democracy, and historical and urban demography. Trained as a generalist, he never identified with narrow subfields or with any single discipline. Indeed, even to characterize his influence in political science alone would distort his intent and misrepresent the consistently interdisciplinary nature of his scholarship. Before turning to his importance in our field, we should at least recognize his immense influence on sociology and history and the profoundly interdisciplinary nature of his work.

As distinct from political science, contemporary sociology is made up of a large number of specialized subfields. Most card-carrying sociologists would be lucky to achieve distinction in as much as a single subfield; Tilly made important contributions to no less than seven sociological subfields. These are: political sociology, social movements, economic sociology, comparative/historical sociology, urban sociology, stratification and inequality, and theory. In one area, comparative/historical sociology, Chuck's work virtually defined the field into existence. In another, social movements, his scholarship helped set in motion a paradigm shift that redefined the study of movements and collective action as the proper province of political and organizational sociologists rather than social psychologists and scholars in the collective behavior tradition. The broad contours of political sociology everywhere bear his imprint.

Tilly's contributions to history are more difficult to pinpoint, since-in implicit polemic with the specializing tendency of much modern historiography-he contributed in equal measure to French, British, European, and world history. And as European historians were moving determinedly away from the study of large-scale social change and towards a "cultural turn" that sometimes left political change in the shadows, Tilly's relentless pursuit of the connections between capitalism, statebuilding, and contention marked him, for some, as a vestige of the out-of-date 1960s. He was hardly that, but younger historians, anxious to set themselves off from their elders, sometimes failed to notice that his methodological innovations were both fundamentally historical and were deeply 